\title{
Pengaruh Aplikasi Android Aneminfo terhadap Pengetahuan dan Sikap Remaja Putri terkait Anemia Defisiensi Besi
}

\author{
Rizki Septia Saraswati ${ }^{1}$, Apoina Kartini ${ }^{1}$, Farid Agushybana ${ }^{1}$ \\ ${ }^{1}$ Fakultas Kesehatan Masyarakat Universitas Diponegoro
}

\section{ABSTRACT}

Background: Iron deficiency anemia is one of the nutritional problems that still occur in Indonesia which is common in young women. Early nutrition education is needed to prevent these problems. The purpose of this study was to analyze the effect of the android-based educational media "Aneminfo" on the knowledge and attitudes of young women regarding iron deficiency anemia.

Method: This research was conducted with a quasi-experimental design with a pre-post control group design with a sample of 37 people for each group taken from 2 vocational schools in the city of Semarang. The intervention was carried out using educational media in the form of the "Aneminfo" android application. Changes in knowledge and attitudes between before and after the intervention were measured using a validated questionnaire and tested using the Wilcoxon and Mann-Whitney tests.

Results: The results showed a significant increase in knowledge in the intervention group ( $p=0.001)$, and there was a significant increase in attitude in the intervention group $(p=0.011)$ compared to the control group. The conclusion of this study is the Aneminfo android application can be an alternative media for the government and health workers in providing education about iron deficiency anemia to increase adolescent knowledge and prevent anemia from an early age.

\section{Correspondence \\ rizkiseptiasaraswati@gmail.com}

\section{Article History}

Received 23 September 2019

Revised 29 January 2020

Accepted 20 April 2020

Available Online 12 June 2020

\author{
Keywords \\ Android \\ Anemia \\ Knowledge \\ Attitude \\ Young women
}

\section{DOI}

10.14710./jpki.15.2.65-69

\section{PENDAHULUAN}

Anemia defisiensi besi adalah anemia yang disebabkan karena kurangnya zat besi yang ada di dalam darah yang akhirnya menyebabkan adanya reduksi sel darah merah dalam tubuh. ${ }^{1,2}$ Remaja merupakan salah satu kelompok rentan yang seringkali menderita anemia, terutama anemia defisiensi besi karena keunikan gaya hidupnya. ${ }^{3}$ Menurut Riskesdas, pada tahun 2018 terdapat $84,6 \%$ wanita usia remaja (15-24 tahun) yang mengalami anemia. ${ }^{4}$ Selain itu, untuk wilayah Provinsi Jawa Tengah, prevalensi anemia berada pada persentase yang cukup tinggi, yaitu $57,7 \% .{ }^{5}$ Kementerian Kesehatan menyebutkan bahwa anemia pada remaja putri menjadi masalah kesehatan bila prevalensinya $\geq 20 \%{ }^{6,7,8}$

Secara umum, remaja yang mengalami anemia dapat mengalami penurunan tingkat kebugaran, terhambatnya pertumbuhan dan perkembangan psikomotor, menurunnya sistem imun, menurunnya daya ingat, tingkat kecerdasan atau IQ, dan daya konsentrasi yang berdampak pada kemampuan belajar menurun dan akan mempengaruhi prestasi belajar remaja. Sselain itu, remaja yang mengalami anemia akan berisiko mengalami KEK sehingga risiko untuk melahirkan anak dengan BBLR dan stunting di kemudian hari akan lebih tinggi. ${ }^{9}, 11$

Pada dasarnya anemia defisiensi besi dapat terjadi karena kondisi asupan gizi besi yang buruk, yang diperparah dengan adanya siklus menstruasi setiap bulannya dan ketidakpatuhan remaja dalam mengkonsumsi tablet Fe. ${ }^{10,12}$ Terdapat beberapa faktor yang mempengaruhi kepatuhan seseorang untuk mengkonsumsi tablet tambah darah, salah satunya adalah pengetahuan yang rendah mengenai anemia dan rendahnya sikap pemenuhan tablet tambah darah itu sendiri. ${ }^{13,14}$

Di era globalisasi saat ini, perkembangan teknologi semakin maju dan pengguna ponsel pintar atau smartphone pun semakin banyak di Indonesia. Menurut Kominfo, pada tahun 2018 terdapat kurang lebih 103 juta pengguna smartphone aktif di Indonesia, naik pesat dari tahun 2017 yang berkisar 86 juta pengguna. ${ }^{15}$ Smartphone memiliki sejumlah fitur yang dapat disesuaikan dengan keperluan penggunanya, termasuk dalam memperoleh informasi kesehatan. Beberapa penelitian menyebutkan bahwa pemanfaatan teknologi kedalam bidang kesehatan dapat menunjang peningkatan pengetahuan masyarakat mengenai informasi kesehatan dengan begitu cepat. ${ }^{16} \mathrm{Hal}$ 
tersebut merupakan peluang untuk meningkatkan digital literasi kesehatan bagi para remaja terutama mengenai anemia defisiensi besi. Penelitian ini bertujuan untuk mengetahui efektivitas dari aplikasi kesehatan berbasis android "Aneminfo", yang berisi informasi kesehatan terkait anemia, dan reminder untuk mengkonsumsi tablet besi. Penelitian ini melihat bagaimana pengaruhnya terhadap pengetahuan dan sikap remaja putri terkait pencegahan anemia.

\section{METODE}

Penelitian ini merupakan penelitian quasi experimental dengan desain pre-post control group design dan dilaksanakan pada bulan Juli hingga Agustus 2019 di 2 SMK di Kota Semarang (SMK Teuku Umar dan SMK Hidayah Semarang).

Populasi dalam penelitian ini adalah seluruh siswi kelas XI dari kedua sekolah tersebut yang telah memenuhi kriteria inklusi dan eksklusi. Kriteria inklusi bagi kelompok intervensi adalah merupakan pengguna handphone android, bersedia menginstal aplikasi Aneminfo dan mengikuti seluruh rangkaian penelitian. Jumlah sampel adalah 37 responden untuk masing-masing kelompok. Sedangkan kriteria eksklusi dari penelitian ini adalah apabila memori handphone tidak mencukupi untuk menginstal aplikasi "Aneminfo", dan tidak mengikuti salah satu dari pretest maupun post test. Penelitian ini telah mendapatkan Persetujuan Etik dari Komisi Etik Penelitan Kesehatan Fakultas Kesehatan Masyarakat Universitas Diponegoro No: 321/EA/KEPK-FKM/2019.

Sebelum intervensi dilakukan, sebelumnya aplikasi android Aneminfo telah divalidasi oleh dua ahli media dan gizi masyarakat. Saat penelitian, kelompok intervensi diberikan perlakuan berupa pemberian edukasi melalui presentasi, dan pemasangan aplikasi android Aneminfo di handphone masing-masing responden yang berisi informasi mengenai anemia defisiensi besi, cara pencegahannya, dan reminder atau alarm untuk mengkonsumsi tablet Fe seminggu sekali.

Penelitian ini dilakukan dalam 2 kali pertemuan. Pertemuan pertama merupakan pertemuan untuk responden pada kedua kelompok. Mereka dipersilahkan untuk mengisi lembar pretest terlebih dahulu. Setelah itu kedua kelompok responden diberikan paparan presentasi mengenai anemia defisiensi besi. Sedangkan pada kelompok perlakuan dipasangkan aplikasi android Aneminfo di handphone masing-masing responden. Responden dipersilahkan untuk mengakses informasi mengenai anemia dan mencoba menggunakan reminder pada aplikasi Aneminfo selama satu minggu ke depan, sedangkan pada kelompok kontrol tidak diberikan. Pada pertemuan kedua, kedua kelompok responden diberikan post test untuk dianalisis perubahan yang terjadi, terutama pada tingkat pengetahuan dan sikapnya. Kelompok kontrol tidak diberikan intervensi berupa pemasangan aplikasi Aneminfo. Namun sesuai dengan etika penelitian, kelompok kontrol tetap mendapatkan edukasi anemia defisiensi besi dalam bentuk presentasi di awal pertemuan setelah pengambilan data pretest.

Pengolahan dan analisis dilakukan menggunakan Microsoft Office 2016 dan SPSS 23.0. Variabel pengetahuan, dan sikap diolah dengan menjumlahkan skor dari masing-masing pertanyaan berdasarkan jawaban yang sesuai, dibagi total skor, dikali seratus. Signifikasi uji statistik $(\mathrm{p}<0,05)$ menggunakan uji Wilcoxon, Paired T-Test, dan Mann Whitney.

Uji Chi-Square digunakan untuk mengetahui signifikansi perbedaan proporsi pada masing-masing kelompok variable yang diteliti. Penelitian ini telah mendapatkan persetujuan etik penelitian dari Komite Etik Fakultas Kedokteran Universitas Islam Sumatera Utara.

\section{HASIL DAN PEMBAHASAN}

Pada penelitian ini sebagian besar responden berusia 16 tahun pada kedua kelompok (kelompok intervensi maupun kontrol). Berdasarkan pekerjaan orangtua, didapatkan bahwa pada kedua kelompok sebagian besar orangtuanya bekerja sebagai karyawan swasta, dengan rerata penghasilan sebesar Rp 2.527.000,pada kelompok intervensi, dan Rp 2.432.000,- pada kelompok kontrol. Penghasilan orang tua pada kedua kelompok ini tidak menunjukkan ada perbedaan yang signifikan, dan kurang lebih sesuai dengan UMK Kota Semarang saat ini. ${ }^{17}$ Selain itu, sebagian besar responden pada kedua kelompok diberikan uang saku antara $\mathrm{Rp}$ 51.000,- hingga Rp 100.000,- oleh orangtuanya dengan rerata uang saku sebesar Rp 74.189,-- pada kelompok intervensi, dan Rp 81.100,- pada kelompok kontrol. Lachat dkk dalam penelitianya mengenai hubungan kondisi sosioekonomi dengan asupan gizi menyebutkan bahwa salah satu yang mempengaruhi besarnya uang jajan anak adalah pendapatan orang tua, semakin tinggi pendapatan orang tua, maka akan semakin besar pula uang jajan anak. ${ }^{18}$

Menurut hasil penelitian diketahui bahwa seluruh responden sebenarnya telah mendapatkan paparan informasi mengenai anemia defisiensi besi sebelumnya. Hal ini tidak mengherankan mengingat materi mengenai anemia secara singkat memang pernah dibahas di jenjang SMP, terutama pada materi biologi kelas 8 mengenai Sistem Peredaran Darah dan Gangguannya. ${ }^{19}$ Namun, tentunya pembahasan mengenai anemia pada jenjang SMP tersebut belum dilakukan secara mendalam dan spesifik. Pada kelompok kontrol, mayoritas responden $(29,7 \%)$ mengaku pernah mendapatkan paparan informasi mengenai anemia sebelumnya melalui media cetak, baik buku pelajaran, majalah, dan lain-lain. Sedangkan pada kelompok 
intervensi, mayoritas (27\%) mengaku mendapatkan paparan informasi mengenai anemia dari teman (Tabel 1).

Pengetahuan merupakan hasil tahu seseorang yang didapat dari hasil pengindraan, yaitu indra penglihatan, pendengaran, penciuman, rasa dan raba. ${ }^{20}$ Pengetahuan mengenai gizi merupakan faktor yang penting dan mempengaruhi perilaku gizi individu, keluarga, bahkan masyarakat. $^{21}$

Hasil dari analisis didapatkan bahwa terdapat perbedaan tingkat pengetahuan yang bermakna $(p=0,0001)$ pada masing-masing kelompok. Pada kelompok intervensi, rerata skor pengetahuan naik dari 64,29 menjadi 76,10. Hal tersebut menandakan adanya perbedaan yang signifikan pada pengetahuan responden antara sebelum dan sesudah menggunakan aplikasi Aneminfo. Hal ini sejalan dengan penelitian yang dilakukan oleh Ratiyun, dkk. yang juga menunjukkan adanya peningkatan pengetahuan yang signifikan setelah responden diberikan pendidikan kesehatan melalui aplikasi android "Sesi-Bugar" $(\mathrm{p}=0,0001) .^{22}$

Selain itu, melalui uji Wilcoxon diketahui bahwa pada kelompok kontrol juga mengalami perubahan pengetahuan yang signifikan $(\mathrm{p}=0,0001)$ dengan kenaikan rerata yang sebelumnya sebesar 71,40 menjadi 75,81. Hal ini dapat terjadi karena walaupun responden tidak mendapatkan aplikasi Aneminfo, namun sesuai dengan etika penelitian responden pada kelompok kontrol tetap diberikan edukasi mengenai anemia defisiensi besi melalui slide presentasi.

Meskipun pada masing-masing kelompok diketahui sama-sama memiliki peningkatan pengetahuan yang signifikan antara sebelum dan sesudah perlakuan, namun setelah dilakukan uji Mann Whitney, diketahui bahwa kelompok intervensi mengalami peningkatan rerata pengetahuan yang lebih besar dibandingkan dengan kelompok kontrol. Pada kelompok intervensi menunjukkan adanya peningkatan rerata pengetahuan sebesar $11,80 \pm 12,30$ sedangkan pada kelompok kontrol hanya mengalami kenaikan rerata sebesar $4,41 \pm 5,48$. Hasil uji Mann Whitney menunjukkan adanya perbedaan pengetahuan yang signifikan antara kelompok yang mendapatkan intervensi dibandingkan dengan kelompok kontrol $(\mathrm{p}=0,001)($ Tabel 2).

Tabel 1. Sebaran subjek berdasarkan karakteristik individu dan keluarga

\begin{tabular}{llll}
\hline \multicolumn{1}{c}{ Karakteristik subjek } & \multicolumn{1}{c}{ Intervensi } & \multicolumn{1}{c}{ Kontrol } & \multicolumn{1}{c}{ Rerata \pm SD } \\
\cline { 2 - 3 } & \multicolumn{1}{c}{ Rerata \pm SD } & $2.432 .000 \pm 951.330,663$ & $0,693^{\mathrm{a}}$ \\
Pendapatan orangtua & $2.527 .000 \pm 1.098 .900,625$ & $81.100 \pm 59.630,530$ & $0,523^{\mathrm{a}}$ \\
Uang Saku & $74.189 \pm 26.732,043$ & Karyawan Swasta & $0,774^{\mathrm{b}}$ \\
Pekerjaan orangtua & Karyawan Swasta & Media Cetak & $0,025^{\mathrm{b}}$ \\
Paparan Informasi & Teman & &
\end{tabular}

Ket:

Signifikansi pada 0,05

$\mathrm{a}=$ Independent T-Test

$\mathrm{b}=$ Chi Square

Tabel 2. Perbedaan tingkat pengetahuan dan sikap responden

\begin{tabular}{|c|c|c|c|c|}
\hline \multirow{2}{*}{\multicolumn{2}{|c|}{ Variabel }} & Kelompok Intervensi & Kelompok Kontrol & \multirow[t]{2}{*}{$\mathrm{P} *$} \\
\hline & & Mean \pm SD (min-max) & Mean \pm SD (min-max) & \\
\hline \multirow{4}{*}{ Pengetahuan } & Sebelum & $64,29 \pm 14,42(42,1-84,2)$ & $71,40 \pm 12,56(31,6-94,7)$ & $0,055^{\mathrm{d}}$ \\
\hline & Sesudah & $76,10 \pm 10,85(52,6-94,7)$ & $75,81 \pm 12,61(36,8-94,7)$ & $0,978^{\mathrm{d}}$ \\
\hline & & $\mathbf{P}=\mathbf{0 , 0 0 0 ^ { b }}$ & $\mathbf{P}=\mathbf{0 , 0 0 0 ^ { b }}$ & \\
\hline & Selisih & $11,80 \pm 12,30((-10,5)-42,1)$ & $4,41 \pm 5,48((-10,5)-10,5)$ & $\mathbf{0 , 0 0 1 ^ { d }}$ \\
\hline \multirow{4}{*}{ Sikap } & Sebelum & $59,82 \pm 14,27(26,7-86,7)$ & $71,53 \pm 16,37(33,3-100)$ & $0,002^{\mathrm{c}}$ \\
\hline & Sesudah & $72,07 \pm 15,7(40-100)$ & $75,13 \pm 16,97(40-100)$ & $0,389^{d}$ \\
\hline & & $\mathbf{P}=\mathbf{0 , 0 0 0 ^ { \mathbf { a } }}$ & $\mathbf{P}=\mathbf{0 , 0 2 7 ^ { \mathrm { b } }}$ & \\
\hline & Selisih & $12,25 \pm 14,69((-13,3)-53,3)$ & $3,60 \pm 9,88((-20)-20)$ & $\mathbf{0 , 0 1 1 ^ { d }}$ \\
\hline
\end{tabular}

Ket:

Signifikansi pada $\mathrm{p}<0,05$

$\mathrm{a}=$ Paired T-Test

$\mathrm{b}=$ Independent T-Test

$\mathrm{c}=$ Wilcoxon Signed Rank Test

d=Mann-Whitney 
Sehingga aplikasi android Aneminfo dapat dikatakan cukup efektif dalam meningkatkan pengetahuan responden pada kelompok intervensi. Penelitian ini sejalan dengan penelitian yang dilakukan oleh Safitri, dkk. yang juga menunjukkan adanya pengaruh pada penggunaan aplikasi android "SEHATI" sebagai media edukasi kesehatan dalam meningkatkan pengetahuan responden $(\mathrm{p}=0,001){ }^{23}$

Sikap merupakan suatu reaksi tertutup dari seseorang terhadap stimulus yang didapatkan. ${ }^{20}$ Edukasi mengenai anemia defisiensi besi yang diberikan diharapkan dapat menumbuhkan sikap yang lebih baik terhadap upaya pencegahan anemia defisiensi besi.

Pada penelitian ini, setelah kelompok intervensi diberikan perlakuan berupa pemasangan aplikasi Aneminfo, hasil penelitian menunjukkan bahwa terdapat peningkatan nilai rerata yang signifikan yang sebelumnya sebesar $69,82 \pm 14,27$ menjadi $72,02 \pm 15,7$ (Tabel 2). Hal ini menunjukkan adanya peningkatan sikap yang signifikan pada kelompok intervensi setelah diberikan perlakuan $(\mathrm{p}=0,0001)$. Selain itu, pada kelompok kontrol juga menunjukkan adanya perubahan sikap yang signifikan antara sebelum dan sesudah $(\mathrm{p}=0,022)$ dengan rerata skor yang sebelumnya $71,53 \pm 16,37$ meningkat menjadi $75,13 \pm 9,88$. Hal ini dapat terjadi karena walaupun responden dari kelompok kontrol tidak diberikan aplikasi Aneminfo, namun sesuai dengan etika penelitian, responden tetap diberikan edukasi mengenai anemia defisiensi besi melalui presentasi. Hasil ini sejalan dengan penelitian yang dilakukan oleh Sharrif, dkk. yang menunjukkan adanya perbedaan yang signifikan pada skor sikap gizi setelah diberikan edukasi gizi. ${ }^{24}$

Terdapat perbedaan rerata yang signifikan pada selisih skor antar kelompok walaupun kedua kelompok sama-sama menunjukkan adanya perbedaan antara sebelum dan sesudah perlakuan. Pada kelompok intervensi, antara sebelum dan sesudah perlakuan menunjukkan peningkatan skor sikap sebesar $12,25 \pm 14,69$, sedangkan pada kelompok kontrol hanya menunjukkan peningkatan sebesar $3,60 \pm 9,88$. Melalui hasil ini dapat diketahui bahwa terdapat perbedaan sikap yang signifikan antara kelompok yang mendapatkan intervensi berupa pemasangan aplikasi Aneminfo dibandingkan yang tidak $(\mathrm{p}=0,011)$. Dengan demikian dapat dikatakan bahwa aplikasi android Aneminfo cukup efektif dalam meningkatkan sikap responden pada kelompok intervensi. Hal ini sejalan dengan penelitian yang dilaksanakan oleh Perdana, dkk. yang menunjukkan bahwa pemberian edukasi gizi melalui aplikasi android mampu meningkatkan tingkat sikap gizi yang lebih baik pada responden. ${ }^{25}$

\section{SIMPULAN}

Aplikasi android Aneminfo dapat menjadi sarana yang cukup efektif dalam memberikan edukasi mengenai anemia defisiensi besi sebagai upaya meningkatkan pengetahuan remaja dan mengingatkan remaja untuk mencegah terjadinya anemia sejak dini. Aplikasi android dapat menjadi salah satu alternatif media yang dapat digunakan sebagai sarana edukasi kesehatan.

\section{KEPUSTAKAAN}

1. Office of Women's Health. Factsheet of Women's Health: Iron-deficiency Anemia. 2017;1-2. Available from: www.womenshealth.gov

2. British Nutrition Foundation. Factsheet: Nutrition, Health and Schoolchildren Iron Deficiency Anaemia. 2018. Avaliable from: www.nutrition.org.uk

3. Dumilah PRA, Sumarmi S. Hubungan Kejadian Anemia dengan Prestasi Belajar Siswi di SMP Unggulan Bina Insani. Amerta Nutr 2017;331-40.

4. Kementerian Kesehatan Republik Indonesia. Riset Kesehatan Dasar 2018. Jakarta, Indonesia: 2018. Available from: $w w w . d e p k e s . g o . i d$

5. Aulia GY, Udiyono A, Saraswati LD, Adi MS. Gambaran Status Anemia pada Remaja Putri di Wilayah Pegunungan dan Pesisir Pantai. J Kesehat Masy 2017;5(1):193-200.

6. Balitbangkes RI. Riset Kesehatan Dasar Republik Indonesia. Jakarta, Indonesia: 2013. Available from: www.depkes.go.id

7. Jaelani M, Simanjuntak BY, Yuliantini E. Faktor Risiko yang Berhubungan dengan Kejadian Anemia pada Remaja Putri. J Kesehat 2017;VIII(3):358-68.

8. Direktur Bina Gizi. Rencana Aksi Pembinaan Gizi Masyarakat (RAPGM) Tahun 2010-2014. Jakarta, Indonesia: 2015. Available from: www.gizikia.depkes.go.id/ter bitan/rencana-aksipembinaan- gizi-masyarakat-rapgm-tahun-20102014/

9. Bobonis GJ, MIguel E, Puri-Sharma C. Anemia and School Participation. J Hum Resour 2006;XLI(4):693-721.

10. Soleimani N, Abbaszadeh N. Relationship between Anaemia, caused from the Iron Deficiency, and Academic achievement among third grade high school female students. Procedia - Soc Behav Sci 2011;29:1877-84.

11. Osungbade KO, Oladunjoye AO. Anaemia in Developing Countries: Burden and Prospects of Prevention and Control. In: Silverberg D, editor. Anemia. Nigeria: InTech; 2012; 115-27.

12. Jalambo MOA. Effect of Iron Supplementation and Nutritional Education among Iron Deficient and Iron 
Deficient Anemic Female Adolescents in the Gaza Strip-Palestine. 2015.

13. Listiana A. Analisis Faktor-Faktor yang Berhubungan Dengan Kejadian Anemia Gizi Besi pada Remaja Putri di SMKN 1 Terbanggi Besar Lampung Tengah. J Kesehat 2016;7(3):455-69.

14. Putri RD, Simanjuntak BY, Kusdalinah. Hubungan Pengetahuan Gizi, Pola Makan dan Kepatuhan Konsumsi Tablet Fe dengan Kejadian Anemia Pada Remaja Putri. J Kesehat 2017;VIII(3):404-9

15. Rahmayani I. Indonesia Raksasa Teknologi Digital Asia. Kementerian Komunikasi dan Informasi Republik Indonesia. 2018.

16. Yani A. Pemanfaatan Teknologi dalam Bidang Kesehatan Masyarakat. PROMTIF J Kesehat Masy 2018;8(1):97-103.

17. Gubernur Jawa Tengah. SK No. 560/68 Tahun 2018: UMK Jawa Tengah Tahun 2019. 2018.

18. Lachat C, Khan L, Khan N, Dung N, Anh N, Roberfroid D, et al. Eating out of home in Vietnamese adolescents: socio-economic factors and dietary associations. J Clin Nutr 2009;90:1648-55.

19. Ruwanto B, Arifin R. SKM (Sukses Kuasai Materi) IPA SMP Kelas VII, VIII, IX. Gramedia Widiasarana; 2016.
20. Notoatmodjo S. Promosi Kesehatan dan Perilaku Kesehatan. Edisi Revi. Jakarta: Rineka Cipta; 2014.

21. Demirozu BE, Pehlivan A, Camliguney A. Nutrition knowledge and behaviours of children aged 8-12 who attend sport schools. Pro-Soc Behav Sci 2012;46:4713-7.

22. Ratiyun RS, Widyawati, Hapsari ED. Pengaruh Pendidikan Kesehatan Melalui Media Aplikasi Android SESI-BUGAR terhadap Pengetahuan tentang Kesehatan Reproduksi Remaja pada Siswa SMP di Kota Bengkulu. 2018.

23. Safitri, Melinda H, Noegroho BS, Husein F, Marhaeni D, Djais JTB. Penerapan Aplikasi Sayang ke Buah Hati (SEHATI) terhadap Pengetahuan Ibu serta Dampak pada Keterampilan Anak. Glob Med dan Heal Commun 2018;6(30):68-73.

24. Shariff Z, Bukhari S, Othman N, Hashim N, Ismail M, Jamil Z, et al. Nutrition education intervention improves nutrition knowledge, attitude and practices of primary school children: a pilot study. Int Electron J Heal Educ 2008;11:119-32.

25. Perdana F, Madanijah S, Ekayanti I. Pengembangan Media Edukasi Gizi Berbasis Android dan Website Serta Pengaruhnya terhadap Perilaku Tentang Gizi. J Gizi Pangan 2017;12(3):169-78. 